\title{
THE SUMMER MEETING IN ITHACA
}

The American Mathematical Society held its seventieth summer meeting at Ithaca, New York from Tuesday through Friday, August 31-September 3, 1965. There were 1470 persons registered at the meeting including 1051 members of the Society. All sessions were held in lecture rooms and classrooms on the campus of Cornell University.

Professor A. P. Calderon of the University of Chicago presented the Forty-Third Colloquium in a set of four lectures with the title Singular integrals. He was introduced at the first lecture by Professor A. A. Albert, President of the Society. Presiding at the other lectures were Professors R. H. Cameron, W. E. Sewell and J. W. Green, the last of whom offered the thanks of the Society to the speaker.

By invitation of the Committee to Select Hour Speakers for Summer and Annual Meetings, Professor George Lorentz of Syracuse University addressed the Society on Applications of entropy to approximation. Professor Maurice Heins presided and introduced the speaker.

There were twenty-six sessions for one hundred seventy contributed papers. Members may wish to know that the number of papers offered for the program was exactly one hundred seventy, the same as the limit set in advance on the number which could be accepted. It was not necessary to turn down any papers for lack of a place on the program.

The chairmen of the sessions for contributed papers were Professors J. H. Bramble, R. J. Bumcrot, S. S. Cairns, S. U. Chase, V. F. Cowling, Louis de Branges, Tomlinson Fort, A. W. Goodman, Emil Grosswald, M. R. Hestenes, J. G. Hocking, S. B. Kochen, J. M. Ortega, L. E. Payne, R. S. Pierce, B. E. Rhoades, Walter Rudin, J. L. Selfridge, S. M. Shah, M. F. Smiley, Lionel Weiss, P. M. Whitman, Dr. H. H. Wicke, Professors Albert Wilansky, P. K. Wong, and Fred M. Wright.

Several organizations cooperated in holding meetings or council meetings on the same campus as the Society and at approximately the same time. These included Pi Mu Epsilon, Mu Alpha Theta, and the Society for Industrial and Applied Mathematics. In particular SIAM presented the John von Neumann Lecture by Professor Freeman J. Dyson of the Institute for Advanced Study, whose topic was Applications of group theory in particle physics.

The Mathematical Association of America held their forty-sixth 
summer meeting. This meeting marked the fiftieth anniversary of the Association. In deference to the Association, the Society yielded a half day of time normally devoted to Society sessions in order to permit the Association to present an expanded anniversary program.

Highlights of entertainment included the traditional SIAM beer party, a chicken barbecue, and an excursion for non-mathematicians to the Corning Glass factory.

The committee on arrangements consisted of $\mathrm{H}$. L. Alder, S. U. Chase, W. H. J. Fuchs, R. Greenblatt, May Kinsolving, E. Pitcher, G. S. Rinehart, A. Rosenberg, G. Sacks, G. L. Walker, R. J. Walker, S. Wainger, H. Widom. Professor Rosenberg was the chairman of the committee throughout more than a year of planning and through August 30. Then Professor R. J. Walker became chairman in order to permit Professor Rosenberg to accept an invitation to participate in a research conference abroad.

The Council met at 5:00 P.M. on Tuesday, August 31, 1965.

The Secretary announced the election of the following one hundred sixty-eight persons to ordinary membership in the Society:

Ackerberg, Robert C., Polytechnic Institute of Brooklyn;

Albert, José A., Ateneo de Manila U, Manila, Philippines;

Allison, Janet Ann, Midwest Stock Exchange Service, Chicago, Illinois;

Aplin, Donald Graham, 508 Park Avenue, Rock Hill, South Carolina;

Armstrong, Gerald M., Brigham Young University;

Bacon, Patrick R., U. S. Navy, Mayport, Florida;

Balch, Michael S., Cornell U;

Ballard, David, Adrian College;

Barbieri, Richard W., Electromagnetic Research, College Park, Maryland;

Bargmann, Valentine, Princeton University;

Baron, John J., Avco, Wilmington, Maryland;

Battistella, Ernesto H., Universidad del Zulia, Maracaibo, Venezuela;

Behboodian, Javad, Pahlavi University, Shiraz, Iran;

Belinfante, Johan G. F., Carnegie Institute of Technology;

Bell, Kenneth F., Oregon State University;

Bird, Elliott H., New Haven College;

Boessenroth, Ted U., Iowa State University;

Bohman, H. Martin., Douglas Missile and Space Systems Division, Huntington Beach, California;

Bohnert, Jackson L., Addressograph-Multigraph Co., Cleveland, Ohio;

Borillo, Mario, C. C. R. Euratom, Ispra (Varese), Italy;

Bowers, Newton L. Jr., G. V. Stennes and Associates, Minneapolis, Minnesota;

de Branges, Carol (Mrs.)., Purdue University;

Brenner, Bard C., University of Miami;

Bucher, William B., U. S. Army Corps of Engineers, Mobile, Alabama;

Calder, James R., Auburn University;

Caler, John W., 7506 Clybourn Avenue, Sun Valley, California;

Cash, Gordon E., Hughes Aircraft Corporation, Fullerton, California; 
Chandy, A. John, Southeastern Massachusetts Technology Institute;

Clauss, Stanley E., IIT Research Institute, Chicago, Illinois;

Cornell, Ross H., State University of New York at Stony Brook;

Coyne, Ronald J., San Diego State College;

Cunningham, Thomas O., Superior Coach Company, Lima, Ohio;

Dauner, Clark D., Washburn University;

Dean, Albert L., Jr., General Electric Company, Phoenix, Arizona;

De Guzman, Miguel, Universidad Deusto, Apdo 1, Bilbao, Spain;

Dembart, Benjamin, California Institute of Technology;

Derrick, William R., Indiana University;

Deutsch, Emeric, Polytechnic Institute of Brooklyn;

Dodge, William J., University of Illinois;

Dragila, Pavel, Str. Tirnava 12, Timisoara, Rumania;

Drews, Dr. Ursula M., Math. Institut der Universität, 34 Göttingen, Germany;

Edgar, Hugh Maxwell Wallace, San Jose State College;

Espinoza, Giudici R., University of Pittsburgh;

Evans, Roger C., Lawrence Radiation Laboratory, Livermore, California;

Everett, William W., Colorado School of Mines;

Fillerup, Charles R., Service Bureau Corporation, Los Angeles, California;

Fink, James P., Stanford University;

Finnegan, Thomas J., Bronx Community College;

Flack, Thomas R., General Applied Science Laboratories, Westbury, New York;

Forte, Aldo, Athens College;

Freedman, Herbert I., University of Minnesota;

Friday, Thomas C., Archer Daniels Midland Company, Minneapolis, Minnesota;

Frink, John A., John Hancock Mutual Life Insurance Company, Boston, Massachusetts;

Galant, David, U. S. Naval Radiological Defense Laboratory, San Francisco, California;

Gan, Berenice, Western Michigan University;

Garlick, Paul K., New Mexico State University;

Gerould, W. Philip, Rand McNally Company, Chicago, Illinois;

Godsey, Gary L., Arizona State University;

Graham, Phyllis A., Indiana State University;

Grantham, Dennis P., Louisiana State University;

Green, James R., Honeywell, Boston, Massachusetts;

Griese, William F., Airborne Instruments Laboratory, Deer Park, New York;

Grinage, Claudette E., General Foods Company, Tarrytown, New York;

Gucker, Frank F., Purdue University;

Gupta, Dr. Subhas C., 88, Ashok Nagar, Agra, U. P., India;

Hall, Robert A., Computer Applications Incorporated, New York, New York;

Hare, Lt. Lynne B., 8th Radio Research Unit, APO San Francisco, California;

Hartzman, Carl S., Purdue University;

Heard, William B., Ent Air Force Base, Colorado Springs, Colorado;

Hooper, Robert C., University of Maryland;

Horowitz, Isaac M., Hughes Aircraft Corporation, Culver City, California;

Howe, Jay W., Trinidad State Jr. College, Trinidad, Colorado;

Hughes, James R., Stetson University;

Humphrey, Jay T., Grambling College;

Hyman, Daniel M., University of Maryland; 
Isemonger, Keith R., Department of the Treasury, Sydney, N. S. W., Australia; Jahn, Edward L., Michigan State Highway Department, Detroit, Michigan;

Johnson, Charles A., University of Missouri at Rolla;

Jones, Ben J., University of Washington;

Karch, Richard R., Yale University;

Katz, Jerome M., Brooklyn College;

Keer, Leon M., Northwestern University;

Kelly, Douglas G., Indiana University;

Klimko, Eugene M., North American Aviation Corporation, Columbus, Ohio;

Knutson, Donald I., Massachusetts Institute of Technology;

Koonce, Lawrence D., Veterans Administration Hospital, Dallas, Texas;

Lee, Kit N. (Mrs.)., Oregon Primate Research Center, Beaverton, Oregon;

Levy-Bruhl, Jacques, Faculté des Sciences, Reims (Maine), France;

Linnin, Yuri V., USSR Academy of Sciences, Leningrad D-11, USSR;

Lipner, Leonard D., University of California, Berkeley;

Liu, Ruey-Wen, University of Notre Dame;

Long, Andrew F. Jr., Duke University;

McDowell, Leland Kitchin, University of Illinois;

McKane, Robert B., New York University-Courant;

McLaughlin, James R., Wayne State University;

Margulies, William, Brandeis University;

Marose, Robert August, Grumman Aircraft Corporation, Bethpage, New York;

Mattingly, Glen E., Sam Houston State Teachers College;

Mellender, James W., A. O. Smith Company, Milwaukee, Wisconsin;

Mendonsa, George L., International Business Machines Corporation, Huntsville, Alabama;

Miller, Donald C., Sylvania Electric Products, Syracuse, New York;

Mitchell, Robert T., Ling Temco Vought, Dallas, Texas;

Montgomery, Edward A., P. O. Box 117, Como, Mississippi;

Muller, Peter J., Yale University;

Nagin, Rhoda P., University of Pennsylvania;

Natkins, Judith, International Business Machines Corporation, Forest Hills, New York;

Nickle, Harry H., Robert College, Istanbul, Turkey;

Olson, Milton P., 7000 Norfolk Road, Berkeley, California;

Oppelt, John A., University of Virginia;

Osman, Mohammed, Oklahoma State University;

Palmer, Daniel J., University of Paris, Paris, France;

Palmer, Edgar M., University of Michigan;

Parker, Henry L., Duke University;

Pena, Deagelia M., University of Michigan;

Pfeffer, Vaclav F., George Washington University;

Plummer, Michael D., University of Michigan;

Potter, Thomas F., University of California, Berkeley;

Reichley, Paul E., Jet Propulsion Laboratory, California Institute of Technology;

Reinhold, Richard C., Ohio State University;

Richardson, Joan, Arizona State University;

Ritter, Rudolf E., Battele Memorial Institute, Geneva, Switzerland;

Rivard, Michael W., 1527 N. W. 10th Street, Miami, Florida;

Robinson, Prentiss N., Polytechnic Institute of Brooklyn; 
Russell, David, Lincoln College;

Rutt, Lt. Gerald D., U. S. Air Force (Communications), MacDill Air Force Base, Florida;

Sabbagh, L. David, Purdue University;

Schuhmann, Martha, Carl Sandburg High School, Orland Park, Illinois;

Serna, Juana, White Sands Missile Range, New Mexico;

Shobert, Judith, Central Bucks Joint Schools, Doylestown, Pennsylvania;

Sickler, Sheldon O., Pasadena College;

Sister Joan Patricia, St. Dominic College;

Sjoerdsma, Theodore J., Dordt College;

Smith, Donald R., Stanford University;

Smith, Linda L., Plainfield Community Schools, Plainfield, Indiana;

Smith, Lyle B., Stanford University;

Sonnenberg, Mark A., Columbia University;

Stager, James A., Purdue University;

Stern, Henry E., National Aeronautical and Space Administration, Huntsville, Alabama;

Stevenson, John C., C. W. Post College;

Stevenson, Robert A., Gonzaga University;

Stolze, Charles H., Polytechnic Institute of Brooklyn;

Swartz, Charles W., Arizona University;

Taner, M. Turhan, Seismic Computing, Houston, Texas;

Terry, Frederick W., Elizabethtown College;

Truitt, Doris A., U.S. Army Missile Command, Redstone Arsenal, Alabama;

Underwood, Donald I., Massachusetts Institute of Technology;

Vamvoukas, Nicholas, Merrill Lynch, Pierce, Fenner and Smith, New York, New York;

Vegh, Emanuel, Naval Research Laboratory, Washington, D. C.;

Velman, John R., Hughes Aircraft Corporation, El Segungdo, California;

Vignone, Anthony F., U.S. Rubber Company, Naugatuck, Connecticut;

Von Der Embse, Urban A., Hughes Aircraft Corporation, Culver City, California;

Ward, Robert G., Allison Division of General Motors, Indianapolis, Indiana;

Wardlaw, William P., University of California, Los Angeles;

Warren, William E., University of California, Berkeley;

Weaver, Billy D., Operations Research, Incorporated, Silver Spring, Maryland;

Weber, James K. Jr., Duke University;

Weiss, Stephen M., Newark College of Engineering;

Whitcraft, Howard Martin, St. Louis University;

Wickramasuriya, S. B. P., Vidyalankara University, Kelaniya, Ceylon;

Williams, Paul F., Continental Assurance Corporation, New York, New York;

Williamson, John B., University of New Mexico;

Winslow, Edward F. Jr., American Cyanamid Company, Sanford, Maine;

Wirth, James F., University of Notre Dame;

Wright, Rozelle B. (Mrs. B. L.)., 472 Putnam Avenue, Apartment 2B, Cambridge, Massachusetts;

Yablon, Marvin, Grumman Engineering Corporation, Bethpage, New York;

Yamaguchi, Itaru, Tokyo College of Science, Tokyo, Japan;

Zarcone, August J., Illinois Institute of Technology;

Zimering, Shimshon, Battele Memorial Institute, Geneva, Switzerland. 
It was announced that the following had been admitted to the Society in accordance with reciprocity agreements with various mathematical organizations:

Societe Mathematique de Belgique: Andre Charles Ducamp.

Chinese Mathematical Society: Yuh-Ching Chen.

Suomen Matemaattinen Yhdistys: Tapani J. Kuusalo.

Societe Mathematique de France: Michel Artola, Rene Dencourt, Pierre Huard, Michel Mendes France, Nam-Cuong Nguyen, Maurice P. Nivat, Rene Pupier, Pierre A. Raviart.

Deutsche Mathematiker Vereinigung: Karl-Heinz Diener, Dr. Siegfried G. Guber, Kurt-Rudiger Kannenberg, Dr. Rolf Lingenberg, Dr. Klaus Peters.

The London Mathematical Society: John W. Baker, A. Howard M. Hoare, Roy Nelson, Alan R. Pears.

Indian Mathematical Society: Dr. Ghanasyam Samal.

Israel Mathematical Union: Bruria Kaufman, Zvi Ziegler.

Mathematical Sociely of Japan: Yoshiomi Furuta, Mineo Ikeda, Kiyoshi Iseki, Akiko Kino, Mineo Kiyohara, Hikosaburo Komatsu.

Wiskundig Genootschap te Amsterdam: Johannes Boersma, Hugo Brandtcorstius, H. Y. A. Duparc, Hans G. Kaper, Hendrik A. Lauwerier, W. Van der Meiden Aida De Miranda Paalman, (Mrs.), Reinder P. Van De Riet.

Norsk Matematisk Forening: Olav A. Laudal.

Schweizerische Mathematische Gesellschaft: Franz W. Kamber, Emil Stamm.

The following sixty-two persons have been elected to membership in the Society on nomination of institutional members as indicated:

University of Alberta: Marilynn L. Faulkner, David A. Klarner, James S. Muldowney, Jitendriya Sarangi, Frank Stenger.

Antioch College: Eloise R. Kleban, (Mrs.), Hugh Lauer, Melvin J. Steinberg.

Arlington State College: Bret E. Evans, Michael J. Norton, Bennett R. Peabody.

Brown University: Nathaniel Chafee, Dr. William J. Gordon, Herbert Kolsky, Marshall J. Leitman, Mahendra G. Nadkarni, Eric P. Salathe, Lawrence Sirovich.

Emory and He nry College: Rex D. Haren, William T. J. Yost, Worth J. Young.

Harvey Mudd College: John T. Allen III, Leo G. Marcus, Larry H. Martin.

University of Houston: Melvin A. Haggart, John P. Vogiatzis.

Lehigh University: Frederick W. Hartmann, Martin J. Hudak, Martin D. Landau, Larry R. Mugridge, Robert E. Powell, John J. Swetits.

University of Massachusetts: Mary K. Bennett, Robert E. McDonald, James J. Tattersall.

University of Michigan: Lowell W. Beineke.

Oakland University: Thomas L. Conley, Ted J. Linstruth, Paul D. Patent.

San Diego State College: Leonard P. Clark, Thomas B. Hoover, Darrell A. Wick.

San Francisco State College: Beverly M. Peterson, Rip R. Talavera.

University of Texas: Harvey L. Baker, Laurence P. Maher Jr., Max K. Miller, Christopher B. Murray, Everett D. Roach, Martin D. Secker.

University of Victoria: Ian Barrodale, David J. Leeming, Henry P. Smith.

University of Virginia: E. Ray Bobo, Junius B. Stroud, Thomas Oscar Vinson Jr.

Western Reserve University: Maia L. Hopper, (Mrs. J. E.), Jerome L. Paul, Alexandra S. Skidmore, (Mrs. R.), Edmond C. Tomastik.

University of Wichita: Hugo Teufel Jr. 
The following Presidential appointments were reported:

As Arrangements Committee for joint meetings of mathematical organizations at Rutgers in August 1966: Louis McAuley, Richard Cohn, Joshua Barlaz, John Bender, F. Eugene Clark, Katherine Hazard, Barbara Osofsky, Malcolm Robertson, Kenneth G. Wolfson.

To the Invitations Committee for Summer Institute 1966: R. P. Boas, Chairman, A. Beurling, L. Ehrenpreis, W. Fuchs, J. Korevaar, and L. A. Rubel.

To the Organizing Committee for Summer Institutes: I. M. Singer, Murray Gerstenhaber; as Chairman: Murray Protter, 1965-66.

To the Committee on Translations: V. L. Klee; Reappointed: Felix Browder, Chairman, and H. A. Antosiewicz.

To the Committee to Advise on the Science Medal: Eldon Dyer, Chairman.

To the Arrangements Committee for the Cornell Meeting: W. H. J. Fuchs.

To the Select Committee for Mathematical Reviews: Armand Borel, Felix Browder, Richard Leibler, G. D. Mostow, Halsey Royden, Norman Steenrod.

As Delegates:

G. Cleaves Byers at inauguration of Raymond Lloyd Smith as President of Michigan Technological University.

George H. Handelman at inauguration of Harold Clark Martin as President of Union College.

Roger Lyndon at inauguration of Harold E. Sponberg as President of Eastern Michigan University at Ypsilanti.

R. E. Dowds at inauguration of Wesley Northbridge Haines as President of Franklin College.

The following have accepted invitations to deliver hour addresses at meetings of the Society:

$\begin{array}{lll}\text { F. V. Atkinson } & \text { Iowa City } & \text { November 26, 27, 1965 } \\ \text { Jim Douglas Jr. } & \text { Iowa City } & \text { November 26, 27, 1965 } \\ \text { Tatsumo Homma } & \text { Lexington, Ky. } & \text { November 12, 13, 1965 } \\ \text { P. S. Mostert } & \text { Lexington, Ky. } & \text { November 12, 13, 1965 }\end{array}$

The Council set a meeting at Victoria, British Columbia, on June 18, 1966. It also voted to invite the Association for Symbolic Logic to cosponsor the 1966 Spring Symposium on Mathennatical Aspects of Computer Science. President Albert reported on a proposal that the Society carry out a Study of Methods and Media for Communication of Mathematical Information, the Study to be supported by the Office of Scientific Information Service of the National Science Foundation. The Council approved that the Society should carry out such a study, and authorized the President to appoint a committee. The Council also approved the proposal by the Conference 
Board of the Mathematical Sciences that it carry on a new survey of the mathematical sciences somewhat along the lines of the so-called Albert survey of 1955-56. The Council approved adding four more volumes to the list of translated Russian monographs, and to publish an index of all the volumes of selected translations up to date. It was also voted to publish the lecture notes of the 1965 Summer Institute in Algebraic Groups under the editorship of Professor Armand Borel and G. D. Mostow. President Albert reported on a meeting with officers of SIAM and representatives of government agencies concerning the possibility of cooperation between the Society and SIAM in arranging symposia and similar meetings in applied mathematics. The Council voted to cooperate with SIAM in the area of applied mathematics, and expressed approval of the suggestion by SIAM that this be accomplished by putting two representative of SIAM on the Society's Committee on Applied Mathematics. The Secretary presented the following resolution concerning Dr. A. J. Lohwater which was unanimously adopted by the Council:

Dr. A. J. Lohwater retired from the Executive Editorship of Mathematical Reviews on May 31, 1965. During his term of office he gave unstintingly of his time and effort and performed an outstanding task in running the Journal. He worked many more hours than can reasonably be expected of an editor and devoted himself wholeheartedly and unselfishly to the job of making Mathematical Reviews the outstanding Journal it is. Be it therefore resolved that:

The Council of the American Mathematical Society expresses its deepest gratitude and appreciation to A. J. Lohwater for his faithful performance going far above the call of duty as Executive Editor of Mathematical Reviews. Dr. Lohwater's skill in guiding the Journal through the increasing complexities of the past five years has performed a task for which the entire mathematical community is exceedingly grateful and without which it could not function properly.

$\mathrm{Be}$ it further resolved that the above text be engraved on a scroll to be presented to Dr. Lohwater by the Secretary of the Society.

There was a business meeting of the Society at $4: 45$ on Thursday, September 2, in Upson Hall, Room B 17. Professor E. G. Begle presided. The Secretary read and those present enthusiastically adopted a resolution of thanks to Cornell University and members of its academic and professional staff for the welcome and hospitality extended to the mathematicians at their 1965 Summer Meetings. He also read the resolution concerning Professor Lohwater which the Council had adopted at its meeting two days earlier. After commenting briefly on the affairs of the Society, the Secretary presented to the membership 
changes in the By-Laws which had been recommended by the Council at its April, 1965, meeting. These changes were concerned with the adoption by the Society of the Journal, Mathematics of Computation, and establishment of its Editorial Committee. The changes were approved by the membership, to go into effect January 1,1966 . The new versions of the several articles and sections concerned follow:

\section{Article III}

\section{Publications Committees}

Section 1. There shall be nine Publications Committees, which shall be the eight Editorial Committees specified in Section 2 of this Article and the Committee on Printing and Publishing specified in Section 3 of the Article.

Section 2. There shall be eight Editorial Committees as follows: committees for the Bulletin, for the Proceedings, for the Colloquium Publications, for Mathematical Surveys, for Mathematical Reviews, a joint committee for the Transactions and the Memoirs, a committee consisting of the representatives of the Society on the Board of Editors of the American Journal of Mathematics, and a committee for Mathematics of Computation.

\section{Article IV}

Section 4. All members of the Council shall be voting members. The method for settling matters before the Council at any meeting shall be by majority vote of the members present. If the result of a vote is challenged, it shall be the duty of the presiding officer to determine the true vote by a roll call vote, each Council member shall vote only once (although he may be a member of the Council in several capacities), and he shall state before the vote in which capacity he votes. The group consisting of the four Associate Secretaries shall have one vote, and it shall be divided equally among those who vote as Associate Secretaries. Each of the nine Publications Committees shall have one vote, and it shall be divided equally among those who vote as members of the respective Publication Committees. All other members of the Council shall have one vote each. Fractional votes shall be counted.

\section{Article XI}

Section 1. The Society shall publish an official organ known as the Bulletin of the American Mathematical Society. It shall publish three journals, known as the Transactions of the American Mathematical Society, the Proceedings of the American Mathematical Society, and Mathematics of Computation. It shall publish a series of mathematical papers known as the Memoirs of the American Mathematical Society. The object of the Transactions, Proceedings, Memoirs, and the Mathematics of Computation is to make known important mathematical researches.

The meeting adjourned at 5:00 o'clock.

J. W. GREeN

Secretary

Everett Pitcher

Associate Secretary

Los Angeles, California

Bethlehem, Pennsylvania 